\title{
GOOD NEWS, BAD NEWS OR JUST NEWS: HOW UK BROADSHEETS PROJECT BRAZIL 1,2,3
}

\author{
Fabiana Mariutti ${ }^{4}$ \\ Ralph Tench ${ }^{5}$ \\ Daniel Buarque ${ }^{6}$
}

\begin{abstract}
In this dynamic global economy countries face increasing pressure to uphold their reputations. Communications play a significant role in this regard, and many outlets frequently report on other countries' affairs. The aim of this paper is to explore and analyse the reputation of Brazil as projected in international news outlets. To build understanding on country reputation based on newspapers, 1,452 news articles about Brazil were explored. The articles were collected from the United Kingdom broadsheet newspapers in four years (2013, 2014, 2015 and 2016) and were categorised according to two dimensions and three classifications (positive, neutral and negative). The study found that the 'Economic, Exports and Business' dimension was used more often. Furthermore, the analysis found the publication of a majority of negative news. The paper contributes to governments in terms of highlighting the countries' improvements and prioritising public policies that can mitigate the negative images stemming from foreign.
\end{abstract}

Keywords: country reputation; country image; government; public policies; Brazil.

\section{BOAS NOTÍCIAS, MÁS NOTÍCIAS OU APENAS NOTÍCIAS: COMO OS BROADSHEETS DO REINO UNIDO PROJETAM O BRASIL}

$\mathrm{Na}$ atual dinâmica economia global, os países enfrentam cada vez mais pressão para defender suas reputações. A comunicação desempenha um papel significativo nesse sentido, e muitos veículos frequentemente relatam assuntos de outros países. 0 objetivo deste artigo é explorar e analisar a reputação do Brasil conforme projetada em artigos de notícias internacionais. Para ampliar o entendimento sobre a reputação do país com base em jornais, foram exploradas 1.452 reportagens sobre o Brasil. Os artigos foram coletados em jornais "broadsheet" do Reino Unido em quatro anos (2013, 2014, 2015 e 2016) e foram categorizados segundo duas dimensões e três classificações (positiva, neutra e negativa). 0 estudo constatou que a dimensão Economia, Exportação e Negócios foi usada com mais frequência. Além disso, a análise encontrou a publicação da maioria das notícias negativas. 0 artigo contribui para os governos em termos de destacar as melhorias dos países e priorizar políticas públicas que possam mitigar as imagens negativas decorrentes do exterior.

Palavras-chave: reputação de país; imagem de país; governo; políticas públicas; Brasil.

1. DOI: http://dx.doi.org/ppp54art10

2. Acknowledgments: we thank the reviewers for their valuable recommendations.

3. Funding: Coordenação de Aperfeiçoamento de Pessoal de Nível Superior (Capes Brasil), Ministry of Education (18670-12-1).

4. Professor at the Post Graduate and Graduate Courses at the Business School at Universidade Positivo - Ecoville, Curitiba, Brazil. E-mail: <famariutti@yahoo.com.br>.

5. Director of Studies and professor at Leeds Business School, England. E-mail: <r.tench@leeds.co.uk>.

6. PhD candidate at King's College, London, England. E-mail: <dbuarque@gmail.com>. 


\section{BUENAS NOTICIAS, MALAS NOTICIAS O SOLO NOTICIAS: COMO LOS BROADSHEETS DEL REINO UNIDO PROYECTAN BRASIL}

En la actual dinámica economía global, los países enfrentan cada vez más presión para defender sus reputaciones. La comunicación desempeña un papel significativo en este sentido, y muchos vehículos relatan asuntos de otros países. El objetivo de este artículo es explorar y analizar la reputación de Brasil conforme proyectada en artículos de noticias internacionales. Para ampliar el entendimiento sobre la reputación del país con base en periódicos, se exploraron 1.452 reportajes sobre Brasil. Los artículos fueron recolectados en periódicos "broadsheet" del Reino Unido en cuatro años $(2013,2014,2015$ y 2016) y se categorizaron según dos dimensiones y tres clasificaciones (positiva, neutra y negativa). El estudio constató que la dimensión Economía, Exportación y Negocios fue usada con más frecuencia. Además, el análisis encontró la publicación de la mayoría de las noticias negativas. El artículo contribuye a los gobiernos en términos de destacar las mejoras de los países y priorizar políticas públicas que puedan mitigar las imágenes negativas derivadas del exterior.

Palabras clave: reputación de país; imagen de país; gobierno; políticas públicas; Brasil.

\section{BONNES NOUVELLES, MAUVAISES NOUVELLES OU NOUVELLES: COMMENT LES JOURNAUX BRITANNIQUES PROJETTENT-ILS LE BRÉSIL?}

Dans l'économie mondiale dynamique d'aujourd'hui, les pays sont de plus en plus confrontés à des pressions pour défendre leur réputation. La communication joue un rôle important à cet égard, et de nombreux véhicules signalent souvent des problèmes d'autres pays. Le but de cet article est d'explorer et d'analyser la réputation du Brésil telle qu'elle est projetée dans les articles de presse internationaux. Pour élargir la compréhension de la réputation du pays sur la base des journaux, 1452 articles sur le Brésil ont été explorés. Les articles ont été rassemblés dans des journaux «broadsheet» du Royaume-Uni en quatre ans $(2013,2014,2015$ et 2016) et ont été classés selon deux dimensions et trois classifications (positive, neutre et négative). L'étude a révélé que la dimension Économie, Exportation et Entreprise était utilisée plus souvent. En outre, l'analyse a révélé la publication de la plupart des nouvelles négatives. L'article aide les gouvernements à mettre en évidence les améliorations apportées aux pays et à prioriser les politiques publiques susceptibles d'atténuer les images négatives de l'extérieur.

Mots-clés: réputation du pays; image de pays; gouvernement; les politiques publiques; Brésil.

JEL: M16.

\section{INTRODUCTION}

While researchers have studied the perceived image of places since the early 1970 s, it is only in the last decade that studies have begun seriously investigating countries' projected image (Anholt, 2010; Dinnie, 2015; Mariutti, 2017). Perhaps consequently, research about the projected image is less popular at present than those about perceived image (Nghiêm-Phú, 2015). To address the gap and to explore and analyse the projection of the reputation of Brazil, this paper analyses news articles from online United Kingdom (UK) broadsheets (credible and serious daily newspapers, Gunter, 2000) about Brazil's image, seeking to categorise and classify thematic dimensions and sub-dimensions from a country reputation perspective. 
"Image" is the term used most often in this context to refer to matters of reputation or perception of a country abroad, which means it can too be used to discuss the projection of a country. Although we will subsequently discuss those definitions in depth, these terms are used interchangeably throughout this paper to refer to the same idea (Jiménez-Martinez, 2017).

This study is grounded in the fact that the media represents one of the stakeholders of a country's reputation (Anholt, 2010; Dinnie, 2015; Lee and Hong, 2012; Toledano and McKie, 2013; Jain and Winner, 2013; Buhmann and Ingenhoff, 2015; Mariutti, 2017). Undoubtedly, a country's branding derives from multifaced spheres, such as economics, politics, and diplomacy, but more than ever, the organisations responsible for those spheres depend on interactions with news outlets and media channels. Indeed, internationally broadcast news about a country may endorse or undermine the country's desired image and its associations. As such, analysing media content can provide insight (Walker, 1997; Hansen and Machin, 2013) into how a country's reputation is shaped on a broad level: For instance, newspaper articles influence the perceptions of a country's status quo along several dimensions, such as economic prominence, exports, global partnerships, famous destinations, cultural festivities, film scenes, and sports recognition, among others. Given the above, we posit that a link may exist between news content and a country's projected image.

We recognise that any type of communication may have the potential to inform and shape people's knowledge about a country's image; however, relative to other channels, the media has also a capacity to influence the decisions of investors and consumers. As a result, several countries have, intentionally or not, examined their image via the global media and thereby understood their own country reputation using several approaches, for instance, South Sudan (Kim and Yang, 2008), Chile (Jiménez-Martinez, 2013), the United States (Jain and Winner, 2013) and Nigeria (Adegoju, 2016).

Country reputation is a multi-dimensional construct. Buhmann and Ingenhoff (2015, p. 67) noted that "a multidimensional model of reputation needs to differentiate it by adding a dimension that captures beliefs regarding the aesthetic qualities of a country, that is its beauty and attractiveness as a cultural and scenic place". However, this field still has many unanswered questions. Part of the issue, as Newburry (2012, p. 3) highlights, is that country reputation "is a diverse topic with many intertwined levels, disciplines and theoretical perspectives". The field has made progress in relating country image to several knowledge domains (Mariutti, 2017), such as media (Custódio and Gouveia, 2007; Kim and Yang, 2008; Lee and Hong, 2012; Jain and Winner, 2013; Buarque, 2015; Adegoju, 2016; JiménezMartinez, 2017); public diplomacy (Szondi, 2007; Newburry, 2012; Buhmann and Ingenhoff, 2015), communications and public relations (Jain and Winner; Loo and 
Davies, 2006; Kim and Yang, 2008; Toledano and McKie, 2013; Buhmann and Ingenhoff, 2015), but paid insufficient attention to theorising country reputation. As a result, the main fields of country reputation, country branding, and nation branding lack consistent, comparable conceptualisations of the country image.

We specifically apply the following definition for country reputation as perceptual interpretations of a country image linked to fixed and temporary associations with the country name, which are built over time in varied stakeholders' minds based on multidimensional images of the country. Clearly, meaningful temporary perceptions may or may not become everlasting images of the country reputation. The reputation of a country insistently conveys (totally or partially) the country identity created by projected (by media) and perceived (by stakeholders) images of the country over time, whether positively, neutrally or negatively. This combination of generalised images (fixed or temporary) carries associations and impressions with a country (Mariutti, 2017).

In order to support a concrete country reputation theory, we first need to delineate the terminologies of country branding and nation branding - related to the image of countries - that exist within the literature. For our study, we treat the image of a country and the reputation of a country as meaningful concepts in literature that are closely interlinked as country reputation contains country image (Giraldi, 2016; Newburry, 2012; Buhmann and Ingenhoff, 2015). However, it is not the scope of this study. It is also important to highlight that literature usually treats country branding and nation branding as interchangeable terminologies; thus, this paper follows this logic for the debate on country reputation. Nevertheless, as a starting point for elucidating our conceptual framework, we define the following terminologies theoretically founded on these referenced authors' studies from this Introduction, as stated next.

1) Country branding applies to branding strategies and communications channels used in marketing and advertising - grounded in the country brand construct. The concept of country brand image encompasses the qualities and associations that the market links with a specific country brand, expressed in situational choices and the brand's reputation.

2) Nation branding functions with the government's engagement with stakeholders using public diplomacy, soft power and long-term campaigns. The focus is also on fostering citizens' participation in the nation's external image and protecting the country's reputation.

Regarding the thematic dimensions of country reputation for this study, several attempts are found in literature. The dimensions of a country's reputation constitute an "area of meaningful future research" (Newburry, 2012, p. 251) that involves questionings and complexities. Certain influences may affect certain dimensions 
more than others: For instance, hosting a mega event might have a greater impact on the country's reputation for tourism abroad - as a dimension - than on the citizens' satisfaction with the accompanying investment. Likewise, social class upgrading, or downsizing might have a stronger impact on the country's economy and criminal activity, and so on. As noted by Nghiêm-Phú (2015), the current debate about analysing countries' projected image is significantly informed by recent investigations into place image. Similarly, in order to explore the themes of news articles on country image, we developed our original framework based on the established dimensions of a country reputation. On this basis, the present paper elaborates on two main thematic dimensions of a country reputation: i) Economic, Exports and Business; and ii) Geocultural and Sustainability. Both have been discussed in country indexes and models by Dinnie (2015), Giraldi (2016), and Anholt (2010). Although there are studies that use different models to analyse images of countries, we believe these are better suited to our evaluation, which aims at understanding if the approach of the news is more positive, negative or neutral. The dimension Economic, Exports and Business encompasses a country's social and economic issues, including its efforts in global advancement and the health of the national and international businesses operating in Brazil. Furthermore, research has conclusively shown that socio-economic changes alter a country's image (Szondi, 2007; 2013) or that it is required reconsidering a country image in times of migration, as Switzerland's current concern (Ingenhoff, 2017). The dimension Geocultural and Sustainability encompasses music styles, cultural festivals, films, mega events, folk gatherings, particular stereotypes, or myths about the country, among other aspects. Meanwhile, sustainability is a more recent dimension that has gained significance in country image (Giraldi, 2016). Anholt $(2010$; 2015) claimed that the environment is the most significant aspect of the image of a country next to technology and education. However, there has been relatively little research on this dimension, even though cultural products such as films, books and music also have a major part to play in determining a country's image (Dinnie, 2015). This leads to the consideration of these creative regarding the potential of a country.

In any way, the news media plays an indispensable role as a stakeholder and an influential channel for protecting, preserving, and/or positioning a country image. With those basic definitions established and the thematic dimension are elucidated, this paper proceeds as follows. The first section provides a review of current literature. The second section explains the study's methods. The final three sections respectively cover the outcomes, data analysis, and final remarks. 


\section{THEORETICAL FRAMEWORK}

\subsection{How newspaper content shapes the reputation of a country}

As stated earlier, the media bear a significant connection to a country's reputation. As several authors have demonstrated, 'media' constitute a stakeholder that can be analysed according to their "news coverage". Upon this basis, many researchers have analysed the association between foreign news and a country's image (Toledano and McKie, 2013; Jiménez-Martinez, 2013, 2017; Jain and Winner, 2013; Lee and Hong, 2012; Szondi (2010), Kim and Yang (2008). Anholt's book Places (2010) dedicated a whole chapter (number 10) to the relation between media and national image. He highlights that governments can utilize several mediums to communicate a country's image, such as newspapers, magazines, television and the Internet. However, word-of-mouth is just as pivotal, if not more so, in shaping perceptions of a country's image. In this vein, Anholt (2010) notes that the image and reputation of a country go beyond communicating its special and positive features in a prestigious newspaper. Instead, the process should begin with understanding that the responsibility for a country's image is split equally between the government and communication professionals: "the fate of the media is as much our responsibility as theirs" (Anholt, 2010, p. 143).

In this regard, it is worth noting that countries are visible every day by the foreign media (Dinnie, 2015). In order to generate positive and authentic images - or at least counteract negative images - about their nations, governments often submit and recommend news coverage to media members as part of their strategies for monitoring the reputation of their countries. Many governments lead media campaigns to narrow the gap between the country's reality and its global perception. Moreover, as media represents one of the key sources for uncovering the image of countries, the government's public relations (PR) involvement along with the newsworthiness and international news coverage are significant (Kim and Yang, 2008).

A key research by Lee and Hong (2012) has evaluated the influence of international public relations on several countries' news coverage and public perceptions of those countries. The authors developed a model for testing the influence of PR (public relations) on a nation's image formation and assessed the United States' image based on news coverage in 27 countries. Their research demonstrates that international public relations affects international news flow and content, and as such, constitutes a long-term strategy for building "a desirable media image toward a nation" (Lee and Hong, 2012, p. 493). Granted, the authors cautioned that "public relations by foreign governments cannot solely explain how prominently or positively (negatively) a country is covered by news media” (op. cit., p. 492). 
Jain and Winner (2013) initiated a major study on country image, pointing out how media functions from a public relations perspective. Jain and Winner (2013) have investigated the United States of America's reputation and performance in 30 countries using a public relations framework, which has examined the relationship that international public relations and U.S.A. news media coverage have with public opinion and their economic performance. Using 1,086 (598 press releases and 488 news media articles) and public opinion data, content analysis was based on Anholt's dimensions (2010). After analysing the data, they concluded that media relations as a public relations function helps to inform the practice of country reputation management. According to the authors, news media is seen as an effective platform "to communicate about a country to its international publics" (Jain and Winner, 2013, p. 110). Based on this previous section, we developed the following rationale for our research.

\subsection{Brazil as the unit of analysis}

In Brazil, there is an ongoing concern about the country's reputation, both locally and globally. One of the greatest challenges concerning the reputation of Brazil is the lack of research in the field compared to other countries. Academic research on the topic has started by mid-2000 at University of São Paulo. Brazil is known as being a country of paradoxes (Rocha, 2000) and also called "the country of many stereotypes" (Buarque, 2015, p. 1310). According to Anholt (2015 apud Buarque, 2016), Brazil has a strong and unique image, associated with joy - "But the nature of the reputation of the country is very light, so this touristic, decorative image is, unfortunately, the wrong one" (op. cit.). In summary, Brazil's image is puzzled and not solid as the reputation is inconsistent (Anholt, 2015 apud Buarque, 2016).

Moreover, due to hosting two mega events (World Cup 2014 and Olympic Games RIO 2016) in the last decade, Brazil has spread its projected image to a worldwide audience - for better or worse. This rare occasion of prolonged international media spotlight into one single country offers a good opportunity for analysis of image projected, which makes the study of Brazil even more interesting as a unit of analysis. Indeed, there are positive and negative features of the image (Mariutti and Tench, 2016) that sometimes stand in sharp contrast: On one hand, Brazil is seen as an exotic and enticing place to visit and discuss; on the other hand, Brazil is currently embroiled in a deep recession (World Bank, 2017). The country made significant economic and social progress between 2003 and 2014: It raised the income level of the poorest 40 per cent, lifted 29 million people out of poverty, and ensured that all citizens have access to primary education (World Bank, 2017). However, these efforts appear to have stagnated since 2015. 
According to an article published by the Reputation Magazine (Transparency..., 2016, p. 2) by the Oxford University Centre for Corporate Reputation,

just in time for the Olympics, Brazil is in meltdown, after nearly two years of what has been called the biggest global corruption scandal ever, with graft and conspiracy identified in epidemic proportions between state-owned oil company Petrobras, construction companies and political leaders.

Convincingly, the British historian expert on Brazil, Kenneth Maxwell (Bandeira, 2016), highlighted that the international image of Brazil could not be worse at this moment; moreover, on his interview to BBC Brasil in March 2016, he said,

The image of Brazil tends to go from euphoria to disaster forecasts. In fact, it is never too good or too bad; as Brazil is a vast country where some things work well and there is an enduring hope for the future. But it is currently very difficult to find something positive amid the tsunami of bad news (Bandeira, 2016).

These serious complications - between having rich natural resources, on one hand, and a tendency toward corruption on the other - are damaging Brazil's country reputation. However, the political or social dimensions of Brazil are beyond the scope of this research, even though it is relevant to hold onto these existing evidences of transitional issues (Szondi, 2007).

Ecologically, Brazil is home to one-third of the world's tropical forests. Few countries have ecosystems as rich, diverse, and important to people's wellbeing as Brazil - thus, a significant part of the country's economy relies on the use of natural resources (World Bank, 2017), such as agribusiness. Moreover,

great progress has also been achieved in reducing deforestation in the rainforest and other sensitive biomes. However, the country still faces major development challenges - especially in finding ways to combine the benefits of agricultural growth, environmental protection and sustainable development (World Bank, 2017).

There are three Brazilian governmental institutions that develop strategies and initiatives aimed at improving the nation's reputation abroad. Embratur, the tourism bureau, manages the promotion of Brazilian destinations under the Marca Brazil brand, launched in 2005. Marca Brazil emphasizes the following attributes for the country brand: joy; sinuosity and curves (of nature and of people's character); luminosity, brightness and exuberance; mix of culture and races; modern and competent. Another institution that promotes Brazil is Apex, which focuses on the progress of trade and business worldwide (Apex-Brasil, 2016). The Media Relations Department at the International Press Office of the Federal Government has also strived to enhance Brazil's global reputation through agenda-setting and international communication. 
Much of the available academic work on Brazil's image deals with the question of analysing specific industries and markets, such as beef (Guina and Giraldi, 2013); tourism (Mariutti, Giraldi and Crescitelli, 2013; Santos and Giraldi, 2017); fresh fruits (Lopes, Giraldi and Aguiar, 2014; Lourenção and Giraldi, 2017); cosmetics (Sutter et al., 2018); country brand' indexes evaluation (Mariutti and Tench, 2016) were also detected; furthermore, most studies adopted quantitative approaches (Mariutti et al., 2017).

Buarque's qualitative study (2015) has analysed the international image of Brazil as projected in the foreign media coverage of the two World Cups held in the country - 1950 and 2014. Employing a theoretical framework linking nation branding and competitive identity for this media coverage research, the Nation Brand Index's dimensions were used as frames to understand the image of a country (people, politics, exports, tourism, culture, and investment). The main results of this content and discourse analysis are as follows. Firstly, it showed that there was an increase in the international visibility of Brazil because of these global sports events; secondly, it confirmed that the frames for describing Brazil have changed from "economy" and "culture" to "politics", and a variation in the news classification from "positive" to "negative". The most stereotypes found in the study were social unrest and protests; passion for football; corruption and World Cup expenses; carnival, party, and samba. Buarque (2015, p. 1314) concludes that "This seems to indicate that the country achieved its goal of using the tournament as part of a broader long-term strategy to enhance Brazil's soft power, prestige, and reputation even if most of the international media has had a negative approach to the country".

According to the British Newspaper Archive (BNA, 2015) at the British Library, the first news regarding Brazil of each century (eighteenth, nineteenth, and twentieth) are designated at box 1 . We discovered 1,071,895 news articles about Brazil that were published from 1 January 1700 to 31 December 1999: 3,406 from the eighteenth century; 704,681 from the nineteenth century, and 360,402 from the twentieth century. These articles covered three centuries of printed media. 


\section{BOX 1}

Headlines in earlier printed newspapers

\begin{tabular}{|c|c|c|}
\hline Publication date & Newspaper and city & Journalistic text \\
\hline $\begin{array}{l}\text { Thursday } \\
3 \text { December } 1711\end{array}$ & \multirow{4}{*}{$\begin{array}{l}\text { Newcastle Courant } \\
\text { Tyne and Wear, England }\end{array}$} & $\begin{array}{l}\text { "Fleet from Brazil, prince from Brazil, Portugal- } \\
\text {-related" }\end{array}$ \\
\hline $\begin{array}{l}\text { Saturday } \\
18 \text { October } 1712\end{array}$ & & "Arrival of the Portuguese Brazil fleet at Lisbon" \\
\hline $\begin{array}{l}\text { Monday } \\
18 \text { October } 1712\end{array}$ & & $\begin{array}{l}\text { "4 days before from the Brazil Fleet, confining of } \\
102 \text { sail, under..." }\end{array}$ \\
\hline $\begin{array}{l}\text { Wednesday } \\
29 \text { October } 1712\end{array}$ & & $\begin{array}{l}\text { "That the Queen was this Morning brought to Bed } \\
\text { of a Son, who was immediately declared Prince } \\
\text { of Brazil" }\end{array}$ \\
\hline $\begin{array}{l}\text { Sunday } \\
12 \text { July } 1716\end{array}$ & Stamford Mercury Lincolnshire, England & "Trade... Brazil" \\
\hline $\begin{array}{l}\text { Saturday } \\
16 \text { December } 1865\end{array}$ & $\begin{array}{l}\text { Yorkshire Gazette } \\
\text { North Yorkshire, England }\end{array}$ & "... The BRAZILS. Rio Janeiro..." \\
\hline $\begin{array}{l}\text { Monday } \\
16^{\text {th }} \text { December } 1867\end{array}$ & $\begin{array}{l}\text { Dundee Advertiser } \\
\text { Angus, Scotland }\end{array}$ & "Brazil" \\
\hline $\begin{array}{l}\text { Monday } \\
2 \text { September } 1867\end{array}$ & $\begin{array}{l}\text { Newcastle Journal } \\
\text { Tyne and Wear, England }\end{array}$ & "Brazil" \\
\hline $\begin{array}{l}\text { Friday } \\
5 \text { March } 1869\end{array}$ & $\begin{array}{l}\text { London Evening Standard London, } \\
\text { England }\end{array}$ & "Brazil" \\
\hline $\begin{array}{l}\text { Tuesday } \\
15 \text { March } 1870\end{array}$ & $\begin{array}{l}\text { Manchester Evening News } \\
\text { Greater Manchester, England }\end{array}$ & "... Exchange on... Brazil" \\
\hline $\begin{array}{l}\text { Saturday } \\
23 \text { November } 1889\end{array}$ & $\begin{array}{l}\text { The Star } \\
\text { Guernsey, Guernsey }\end{array}$ & "... Tranquillity continues to prevail in Brazil..." \\
\hline $\begin{array}{l}\text { Monday } \\
1 \text { January } 1900\end{array}$ & $\begin{array}{l}\text { Manchester Courier and Lancashire } \\
\text { General Advertiser Greater Manchester, } \\
\text { England }\end{array}$ & "... trading between ... various parts Brazil..." \\
\hline $\begin{array}{l}\text { Monday } \\
1 \text { January } 1900\end{array}$ & $\begin{array}{l}\text { Morning Post } \\
\text { London, England }\end{array}$ & "... Rescission Bonds? 1899 Brazil..." \\
\hline $\begin{array}{l}\text { Monday } \\
1 \text { January } 1900\end{array}$ & $\begin{array}{l}\text { Birmingham Daily Post } \\
\text { West Midlands, England }\end{array}$ & $\begin{array}{l}\text { "China, Japan, \&c.-Correspondence eX Armand } \\
\text { Behie, via Martlles, in course of to-day. -: Brazil and } \\
\text { River Platea-Mains" }\end{array}$ \\
\hline $\begin{array}{l}\text { Monday } \\
1 \text { January } 1900\end{array}$ & $\begin{array}{l}\text { Lincolnshire Echo } \\
\text { Lincolnshire, England }\end{array}$ & "ALMOND NUTS. WALNUTS. BRAZILS." \\
\hline
\end{tabular}

Source: BNA (2015). 
In the eighteenth century, there two printed newspapers that mentioned Brazil. The first one, published in Newcastle in 1711 and the second one in 1712, cited "Brazil" in relation to marine transportation; the text is not completely clear, but seems to reference ships from ships from the colonised country (1530-1815) under the power of Portugal - D. Pedro II, the prince of Portugal. The second article, published in Lincolnshire, England in 1716, was related to trade and commercial transactions.

Six printed newspapers referenced "Brazil" in the nineteenth century, but strangely, these publications were limited to the latter half of the century. One of the news articles, published in North Yorkshire in 1865, mentioned "Rio de Janeiro" and expressed the diversity in the country by using the word "Brazils". In 1867, there were two single references regarding the word "Brazil", published in Angus, Scotland and Newcastle, England; yet no further context is shown. In 1869, London's first publication on the topic mentioned "Brazil". In 1870, a Manchester news article used "exchange" in the headline, it is possible that it applies to the English ports' significance in international trade at that time.

Interestingly, in 1889, there was a newspaper in Guernsey (a British island northwest of France) that announced: “... Tranquillity continues to prevail in Brazil...” - probably referring to the formation of the first Brazilian republic following the overthrow of Pedro II, Brazil's second and final emperor; the Brazilian monarchy was established in 1822, when Portugal's crown prince, Dom Pedro, defied his Parliament and proclaimed an independent Brazil under his rule (Brazil..., [s.d.]).

In the twentieth century, the news mostly revolved around commerce topics, such as global trade with China and Japan; nuts from Brazil; loans among countries - 'Rescission Bonds'that is related to law in international banking. Nevertheless, as a limitation of the interpretation for the twentieth century is that the texts are not quite understandable.

Overall, the most surprising aspect of these earlier publications was the geographical issue, since most of the newspapers were based in the north of England - possibly because of the ports. Furthermore, these few printed newspapers confirm that commercial relations between Brazil and England were relevant, informative and publishable. In fact, the articles highlight that the "Economic, Exports and Business" dimension was the most mentioned country reputation dimension in the last three centuries.

A major limitation on this search was that no further context of each news article was investigated. Evidently, the above examination does not constitute a historical analysis, but was merely useful for establishing a record and baseline for Brazil's country reputation.

The next section details the method procedures that underlie this study. 


\section{METHODS}

\subsection{United Kingdom broadsheets: significance and structure}

More than two decades after the digital revolution in newspaper journalism (Fortunati, Taipale and Farinosi, 2014), the world has seen a rapid increase in the consumption of online news (Ghersetti, 2014). Thus, newspapers are repositioning themselves as multi-platform publishing entities (Fill, 2011). As stated by Ghersetti (2014, p. 375), "media professionals and scholars have described online news as focused on topicality, presenting short, fast and straight stories" - making it applicable to country reputation dimensions that typically comprise a country's reputation.

The change to online publication presents new challenges in researching the news media, such virtual media outlet provides opportunities for innovative procedures of data analysis, allowing re-evaluating theories on "country image" and inspire the progress of news coverage methods. For Richardson (2007, p. 7), identifying that newspapers are businesses is "the starting point of analysis, not the conclusion". Furthermore, Walker (1997, p. 56) stated that "news strategy is what follows for media relations from an authority's overall plan of campaign". Based on this, media relations between government PR offices and journalists are vital, as stated by Tench, Bowd and Jones (2007, p. 368), "journalists act as a lens of interpretation and filter news stories to the public".

According to National Readership Survey, ${ }^{7}$ the newspapers are an important element of the mass media, and approximately one-third of adults in Great Britain read at least one national newspaper each day. For Gunter (2000), broadsheet newspapers represent the serious, up-market press in Britain: They provide more in-depth coverage of business, economics, and international affairs than tabloids, and are thus viewed as a credible and reliable source of information (LexisNexis, 2014).

\subsection{Sampling}

The study in this paper adopted a single case study approach, analysing the content and themes of selected UK broadsheet news articles in order to understand the projected image of Brazil and to elucidate the complexities of a country's reputation. The set of UK broadsheets we used contained nine publications - "broadsheet newspapers represent the serious, up-market press in Britain, which specialises in providing in-depth coverage of news stories" highlighted Gunter (2000, p. 405). Moreover, newspapers also provide updated secondary data (Saunders, Lewis and 
Thornhill, 2009). Box 2 shows the distribution of news publications in the United Kingdom separated by their types.

BOX 2

National UK newspaper groups

\begin{tabular}{|l|l|l|}
\hline \multicolumn{1}{|c|}{ Tabloids } & \multicolumn{1}{|c|}{ Mid-markets } & \multicolumn{1}{c|}{ Broadsheets } \\
\hline $\begin{array}{lll}\text { The Sun } \\
\text { The Sun on Sunday }\end{array}$ & $\begin{array}{l}\text { The Express } \\
\text { The Sunday Express }\end{array}$ & $\begin{array}{l}\text { The Times } \\
\text { The Sunday Times }\end{array}$ \\
\hline $\begin{array}{ll}\text { Daily Mirror } \\
\text { Sunday Mirror }\end{array}$ & $\begin{array}{l}\text { The Daily Mail } \\
\text { The Mail on Sunday }\end{array}$ & $\begin{array}{l}\text { The Guardian } \\
\text { The Observer }\end{array}$ \\
\hline $\begin{array}{ll}\text { Daily Star } \\
\text { Daily Star Sunday }\end{array}$ & & $\begin{array}{l}\text { The Independent } \\
\text { The Independent on Sunday }\end{array}$ \\
\cline { 3 - 3 } The People & & $\begin{array}{l}\text { The Daily Telegraph } \\
\text { The Sunday Telegraph }\end{array}$ \\
\cline { 3 - 3 } & & The Financial Times \\
\hline
\end{tabular}

Source: The Migration Observatory at the University of Oxford (Gunter, 1985).

\subsection{Data collection}

For the collection the data as previously described, this study used the LexisNexis Group, which is an internet-format database - "for providing computer-assisted legal research as well as business research and risk solution services. During the 1970s, LexisNexis pioneered the electronic accessibility of legal and journalistic documents" (LexisNexis, 2014). For Sauders, Lewis and Thornhill (2009, p. 72), LexisNexis, in research, plays a role as a tertiary literature source, which "also helps you to allocate secondary data" (p. 264). LexisNexis offers "media coverage from approximately 12,000 publications, national and local newspapers, press releases, transcripts of TV broadcasts, newswires, statistical bulletins, magazines and trade journals" (Sauders, Lewis and Thornhill, 2009, p. 72). One of the recent tools is the LexisNexis Searchable Directory of Online Sources "Source Locator", which is a powerful new tool for retrieving targeted information about more than 40,000 LexisNexis sources (LexisNexis, 2014).

Regarding the news search, the results from the collected news lists were downloaded in .pdf file showing the chronological order of the news (the newest to the oldest) during the specific period, numerically marked. Additionally, it displays the whole article, including the newspaper's logo, the date, and the length of the article news; perhaps the section, the pages and the writer (occasionally) are cited. "Brazil" is always in red both in the headline and in the text, due to the fact that it was the searched word. The analysis did not include searches for the word "Brazilian". Next, four examples of the news saved in .pdf files collected from LexisNexis (figures 1 to 4 ), which were also the internal source at $\mathrm{NVivo}^{8}$ (data analysis software), are shown next. 
FIGURE 1

The Times from LexisNexis

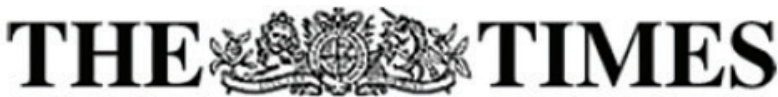

The Times (London)

December 13, 2014 Saturday

Edition 2;

National Edition

\section{Brazilian serial killer did it for the 'buzz'; \\ Brazil}

BYLINE: James Hider

SECTION: NEWS; Pg. 49

LENGTH: 401 words

A Brazilian serial killer has admitted to strangling or stabbing to death 42 people, almost all of them women, for the adrenaline rush. His killing spree in Rio de Janeiro lasted almost a decade.

Police arrested Sailson Jose das Gracas, 26, on Wednesday, shortly after he had knifed a woman to death in the north of the crime-ridden city which will host the Olympics in 2016.

"At 17, I killed the first woman and that gave me a buzz. I kept on doing it and I enjoyed it," he said. "When I wasn't killing someone, I got uptight. I would pace up and down at home. Killing calmed me down.

"I'd kill someone and then would think about the victim for two or three months. After that, l'd go off hunting. don't feel remorse - if I go to jail for ten, 15, 20 years, then as soon as I get out I'll do the same thing all over again." The maximum jail term in Brazil is 30 years.

Gracas is the latest in a spate of serial killers to plague the country, which has one of the highest murder rates in the world. Last week a 23-year-old man was arrested near Sao Paulo for beheading six people in random axe attacks that he said were inspired by watching Islamic State (Isis) videos. In October, a

Source: LexisNexis (2014). 
FIGURE 2

The Independent from LexisNexis

50 of 107 DOCUMENTS

\section{The ONDEDENDENT \\ The Independent (London) \\ September 24, 2014 Wednesday \\ First Edition}

\section{Brazil refuses to sign up to deforestation pledge}

BYLINE: DAVID USBORNE AT THE UNITED NATIONS

SECTION: WORLD: Pg. 32

LENGTH: 325 words

Brazil has refused to sign an anti-deforestation pledge. dealing a blow to the Climate Change summit in New York.

The Brazilian delegation claimed measures to end illegal deforestation had been drafted behind closed doors at the United Nations without its participation.

The fit of pique gravely undermines the declaration, which was meant as a centre-piece of the one-day summit. The Amazon jungles, "the lungs of the planet", absorb huge quantities of carbon dioxide, the main cause of global warming. Logging is the second biggest source of emissions.

Source: LexisNexis (2014). 
FIGURE 3

The Guardian from LexisNexis

\title{
theguardian
}

The Guardian (London) - Final Edition

October 15.2014 Wednesday

Football: In brief: Brazil: Neymar to the fore as Japan are swept aside

BYLINE: Guardian staff and agencies

SECTION: GUARDIAN SPORT PAGES: Pg. 5

LENGTH: 182 words

\begin{abstract}
Neymar scored all four goals in a sumptuous display for Brazil as the five-times world champions routed an understrength Japan 4-0 in a friendly in Singapore to maintain Dunga's perfect start since returning as manager. The Brazil captain took his impressive tally to 40 goals in 58 matches. Neymar had no problems with the poor surface as the Barcelona striker entertained the 51.577 crowd with flicks and tricks around his $\infty 00$ finishes. He rattled the post with a free-kick a minute before opening the scoring in the 18 th minute when he rounded the Japan goalkeeper, Eiji Kawashima, and lashed the ball into an empty net after being put clear by Diego Tardelli. Philippe Coutinho then slipped a ball to Neymar, who slotted home a second. Dunga brought on the experienced Robinho and Kaka to get among the scoring fun. Kaka almost obliged with his first touch, but his 77 th-minute header was pushed on to the bar by Kawashima. Japan failed to clear and Neymar swept home. Kaka then turned provider as he swung over a cross from the left that Neymar leapt highest to head in. Staff and agencies
\end{abstract}

LOAD-DATE: October 15. 2014

LANGUAGE: ENGLISH

PUBLICATION-TYPE: Newspaper

Source: LexisNexis (2014). 
FIGURE 4

The Financial Times from LexisNexis

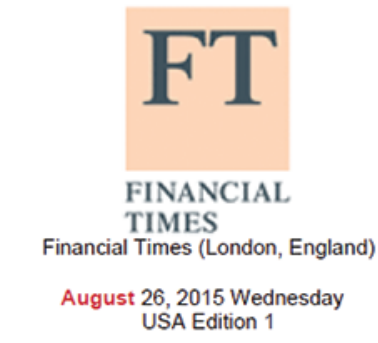

\title{
Gloomy economic reality dawns on Brazil; \\ Recession
}

BYLINE: John Paul Rathbone in Sao Paulo

SECTION: WORLD NEWS; Pg. 3

LENGTH: 689 words

\begin{abstract}
Roberto Setubal, the head of Brazil's biggest private bank, sees a long period of gloom for Brazil's economy as unemployment rises and Congress is upset by corruption scandals. However, he does not believe Dilma Rousseff, the president, will be impeached.
\end{abstract}

Latin America's largest economy has fallen into its biggest recession since the Great Depression, hit by lower commodity prices, a multibillion-dollar corruption scandal at state-controlled oil company Petrobras, and a nolitical crisis that has made Ms Rousseff the most unnonular nresident in Rrazilian demor.ratic. histonv

Source: LexisNexis (2014).

\section{FINDINGS AND DATA ANALYSIS}

Our data set represents an extensive number of articles across four years - 2013, 2014, 2015 and 2016 distributed in eight semesters - that spanned sport megaevents, social changes, and political problems in the country. For this current news coverage about Brazil, box 3 shows the data collection distributed into semesters with the main facts on the country.

BOX 3

Time frames for the news coverage

\begin{tabular}{|c|c|c|c|}
\hline Semester & News & Total by year & Main facts in Brazil in each semester \\
\hline $\begin{array}{l}\text { January to June } \\
2013\end{array}$ & 244 & \multirow[b]{2}{*}{474} & Economy growth decreases and street demonstrations \\
\hline $\begin{array}{l}\text { July to December } \\
2013\end{array}$ & 230 & & Selected to host the Olympics 2016 in Rio de Janeiro in July 2013 \\
\hline $\begin{array}{l}\text { January to June } \\
2014\end{array}$ & 210 & \multirow[t]{2}{*}{404} & World Cup 2014 in July 2014 and street demonstrations \\
\hline $\begin{array}{l}\text { July } 2014 \text { to } \\
\text { December } 2014\end{array}$ & 194 & & Presidential re-election in October 2014 and street demonstrations \\
\hline
\end{tabular}


(Continued)

\begin{tabular}{|l|c|c|l|}
\hline \multicolumn{1}{|c|}{ Semester } & News & Total by year & \multicolumn{1}{|c|}{ Main facts in Brazil in each semester } \\
\hline $\begin{array}{l}\text { January to June } \\
2015\end{array}$ & 92 & \multirow{2}{*}{266} & Street demonstrations and corruption scandals \\
\cline { 1 - 2 } $\begin{array}{l}\text { July to December } \\
2015\end{array}$ & 174 & \multirow{2}{*}{308} & Street demonstrations; environmental disaster and corruption scandals \\
\cline { 1 - 1 } $\begin{array}{l}\text { January to June } \\
2016\end{array}$ & 161 & $\begin{array}{l}2016 \text { Olympic Games in Rio de Janeiro and } \\
\text { Zika issues }\end{array}$ \\
\cline { 1 - 1 } $\begin{array}{l}\text { July to December } \\
2016\end{array}$ & 147 & $\begin{array}{l}\text { Environmental disaster and } \\
\text { corruption scandals }\end{array}$ \\
\hline
\end{tabular}

Authors' elaboration.

Next, chart 1 , as the summary of the news by semesters, shows the decline of the news in 2015.

CHART 1

Summary of number the news by semester and year (2013-2016)

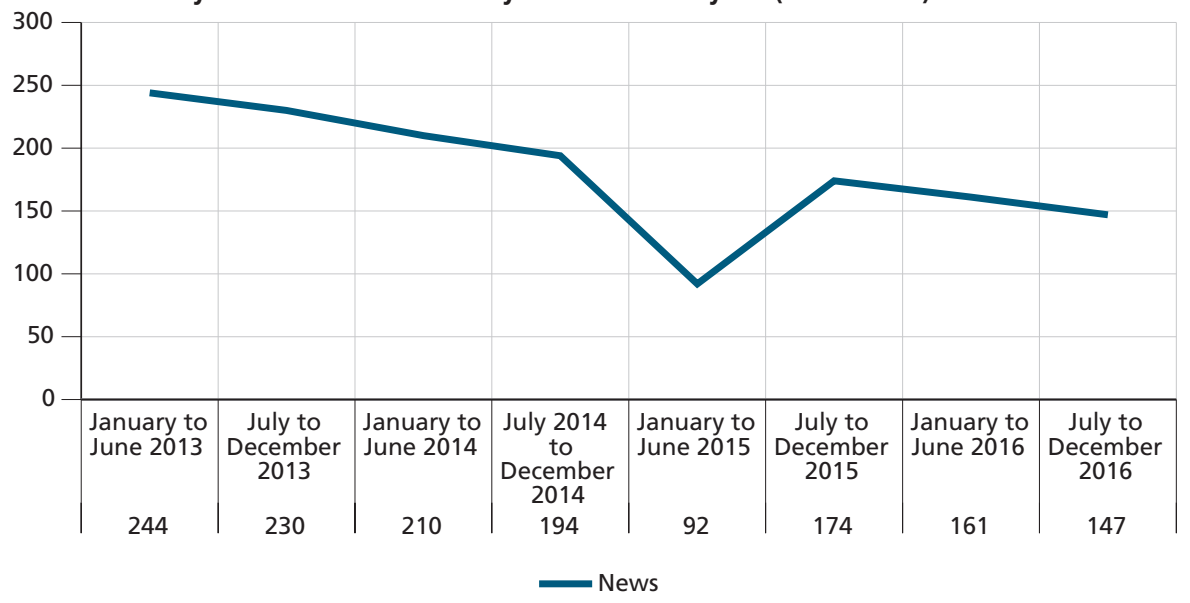

Authors' elaboration.

\subsection{Data analysis}

To provide some context for the articles, as a matter of fact, while the authors were analysing and interpreting these collected data, the UK newspapers were widely exposing the current situation of Brazil as "a tragedy and a scandal" (The Guardian..., 2016). Moreover, "corruption, conspiracy accusations and an impeachment battle - the turmoil surrounding Brazilian politics" (Brazil..., 2016) and "Nothing is clear in Brazil's murky political crisis, except that the country will suffer the consequences for a long time to come" (The Guardian..., 2016). The Independent (Watts, 2016) said: "But beneath the colourful façade, Brazil is a darker place, one where social division and corruption have forged one of the world's most violent civilisations". 
Because articles communicate an underlying tone with varying terminology (as images type), we classified each article in this way: Articles were "positive" if they were essentially "good news", negative if they were "bad news", and neutral if they did not present any negative or positive news ("just news" as used in the title of this paper to mean that there was no judgement of value attached to it) this classification is in line with the approach utilized by Morley (2002), Jain and Winner (2013) and Hansen and Machin (2013). In this case, each news articles headline was associated to the Brazil's image type coded by one node. Although the analysis of the tone used in the news coverage is generally subjective, this study follows Buarque (2015) in accepting that the description of problems in the country is bad for its image, even if it could generate a more nuanced interpretation about the meaning and consequence of such problems. In order to classify the articles for analysis, we first inspected the headline for key words, treating it as the formal criterion for segmentation (Schreier, 2013). If the headline was illegible, we read the whole article for distinguishing sentences. Le's (2012) news coverage of the French quality daily, Le Monde has also used headlines to explore "news at a glance".

After this initial step, we used thematic analysis (Schreier, 2013) and content analysis (Morley, 2002) to explore, classify, and interpret the data from the articles' content. Following the suggestions of Hansen and Machin (2013), we conducted a content analysis on the classified articles to be linked to country branding perspective (Fetscherin, 2010; Szondi, 2007; Moilanen and Rainisto, 2009; Anholt, 2010; Lee and Hong, 2012; Jiménez-Martinez, 2013, 2017; Dinnie, 2015). For Morley (2002, p. 213), content analysis "will provide a classification of the content of each press report" - for instance, if it is negative, neutral or positive. Similarly, Walker (1997, p. 79) already observed that government authorities "communications need to be defined much more widely than media relations". He was clear to mention, "The authority may choose to put efforts into direct communication", because for him, media relations are indirect communications meaning "talking to the press and broadcasters the local authority is seeking to use them to convey a message" (Walker, 1997, p. 78). Moreover, Kim and Yang (2008) has also applied content analysis of international newspapers and government publications, for examining the influence of newsworthiness and public relations efforts on international news coverage.

For the purpose of thematic and content analysis, the data analysis was carried out using NVivo analytical software that helps to "ensure rigour in the analysis process" (Bazeley and Jackson, 2013, p. 3). Figure 5 shows one of the NVivo's screenshot regarding the coding framework for the country image type (positive, neutral or negative). Therefore, using a qualitative approach, we followed the recommendations for category development set up in NVivo (for the thematic dimensions) by Bazeley and Jackson (2013), which involved the following analytical processes: reading, reflecting, coding, annotating, memoing, discussing, linking, and visualising. As a quantitative analysis tool, NVivo is a useful way "to build a web of understanding and the beginnings of theory” (Bazeley and Jackson, 2013, p. 243). 
During the analysis, for each article, we identified the main topic and stored the article in one of two thematic dimensions i) "Economic, Business and Exports"; or ii) "Geocultural and Sustainability". Fundamentally, coding is a way of tagging (Bazeley and Jackson, 2013, p. 70) in order to "bring order out of chaos". Next, we determined the twenty-two sub-dimensions (figure 6), which are also related to the previous studies and related to the news' content. It is relevant to say that the numbers of news represent part of the data analysis, not the total of news. 


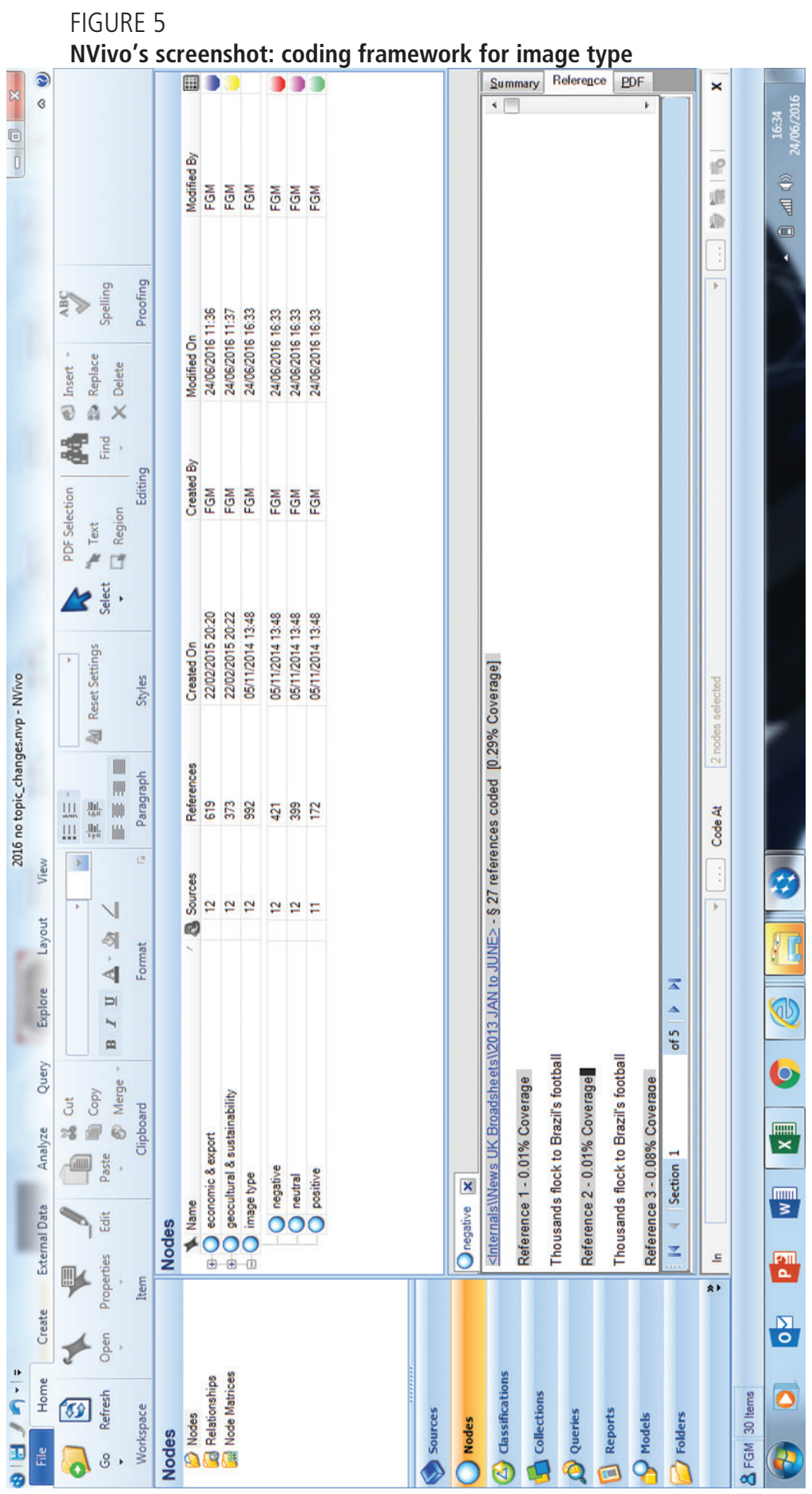

Authors' elaboration. 
FIGURE 6

Twenty-two sub-dimensions at NVivo coding stage

\begin{tabular}{|c|c|c|}
\hline Name & Sources & References \\
\hline - economic \& export & 12 & 619 \\
\hline agribusiness, oil \& ethanol & 8 & 51 \\
\hline corruption & 10 & 43 \\
\hline diplomatic issues & 9 & 40 \\
\hline fashion & 4 & 6 \\
\hline 0 finance & 12 & 97 \\
\hline government & 12 & 117 \\
\hline internet, social media \& mobile & 6 & 12 \\
\hline investment & 11 & 45 \\
\hline polititcs & 11 & 77 \\
\hline poverty & 3 & 5 \\
\hline . tourism & 7 & 49 \\
\hline ๑. UK business with Brazil and a few other countr & 11 & 77 \\
\hline geocultural \& sustainability & 12 & 373 \\
\hline 0 accidents & 3 & 10 \\
\hline 0 crime and violence & 8 & 50 \\
\hline O dance & 1 & 1 \\
\hline drugs & 4 & 4 \\
\hline environmental issues & 10 & 76 \\
\hline film, tv \& radio & 6 & 14 \\
\hline 0 food & 3 & 4 \\
\hline music & 2 & 5 \\
\hline 0 religion & 6 & 28 \\
\hline sports & 6 & 177 \\
\hline women discrimination & 1 & 4 \\
\hline O image type & 12 & 992 \\
\hline negative & 12 & 421 \\
\hline neutral & 12 & 399 \\
\hline$\ldots$ positive & 11 & 172 \\
\hline
\end{tabular}

Authors' elaboration.

\subsection{Project Country Image: good, bad or just news}

The negative and positive classifications are clearly reasonable as the damaging and the confident associations to the country image, respectively. Neutral classification was the purely informative news content. For the purpose of impartiality due to the significance of each news article's circumstance - e.g. negatively, neutrality or 
positively position, this coding frame was carefully analysed and interpreted by a non-discriminatory Brazilian researcher's perspective. After careful analysis as described at the previous section, the news classifications were summarized in the pie chart below.

\section{CHART 2}

News Articles' classification as positive, neutral, or negative

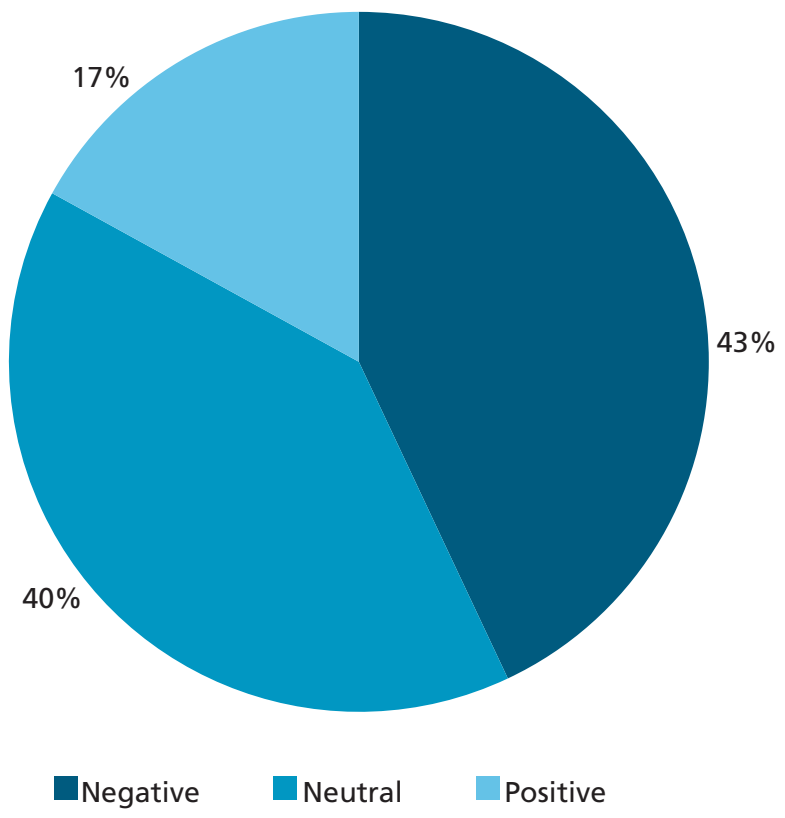

Authors' elaboration.

Obs.: Image displayed in low resolution due to the technical characteristics of the original files provided by the authors for publication (editorial note).

The whole dataset of the four years analysed shows that there was a prevalence of news pieces with a negative approach to describing Brazil. This is a portrait of the projection of the image of Brazil in a period in which the international media was paying more attention to the country, but the nation was going through a very deep political and economic crisis, which naturally affected the tone used to describe it. While the percentage of news with a neutral approach is also high (probably due to objective and factual descriptions of the country with no value in the projection), more strikingly is the fact that the total of news with a positive tone is less than one in every five pieces about Brazil. 


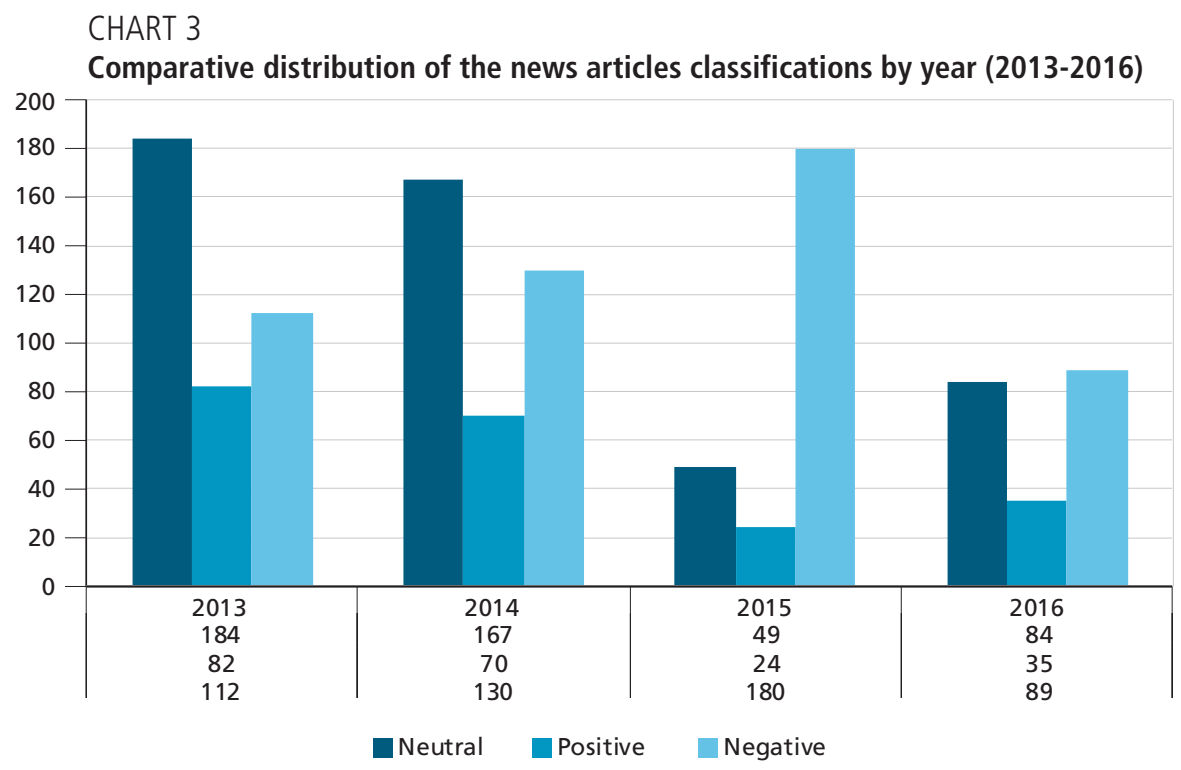

Authors' elaboration.

When analysing each year separately, the most striking observation is that most of the news articles from 2013 and 2014 presented a neutral theme, amounting to $48 \%$ and $45 \%$ of the total number of news in each of those years. In 2014 , there were more negative articles than the year before $(35 \%$ of the total of news that year), but seventeen fewer neutral articles and twelve fewer positive articles. It is noteworthy to mention that the total of news in each year do not match the numbers of box 3 and chart 1 (whole dataset), due to the fact that the chart 3 presents the analysed data; some news articles were repeated by the outlets.

The year 2015, on the other hand, was the one with a biggest margin of negative $(71 \%$ of the total of the year) over positive $(9,4 \%)$ and neutral news (19\%). The main facts mention about the country in the analysed newspapers in that year were street demonstrations, corruption scandals, and an environmental disaster. As it was the gap year between the World Cup and the Olympics, the coverage focused less on the global events (which may have a tendency of generating positive, festive news) and more on the problems the country was going through (including problems related to the legacy of the World Cup that had ended and the preparations for the upcoming Olympic Games). 


\subsection{News articles' classification as thematic dimensions and sub-dimensions}

Regarding the news articles' classification as thematic dimensions, chart 4 illustrates them by year. As can be seen from chart 4, the "Economic, Exports and Business" thematic dimension reported significantly more news than the "Geocultural and Sustainability" dimension.

CHART 4

Number of news articles by thematic dimensions (2013-2016)

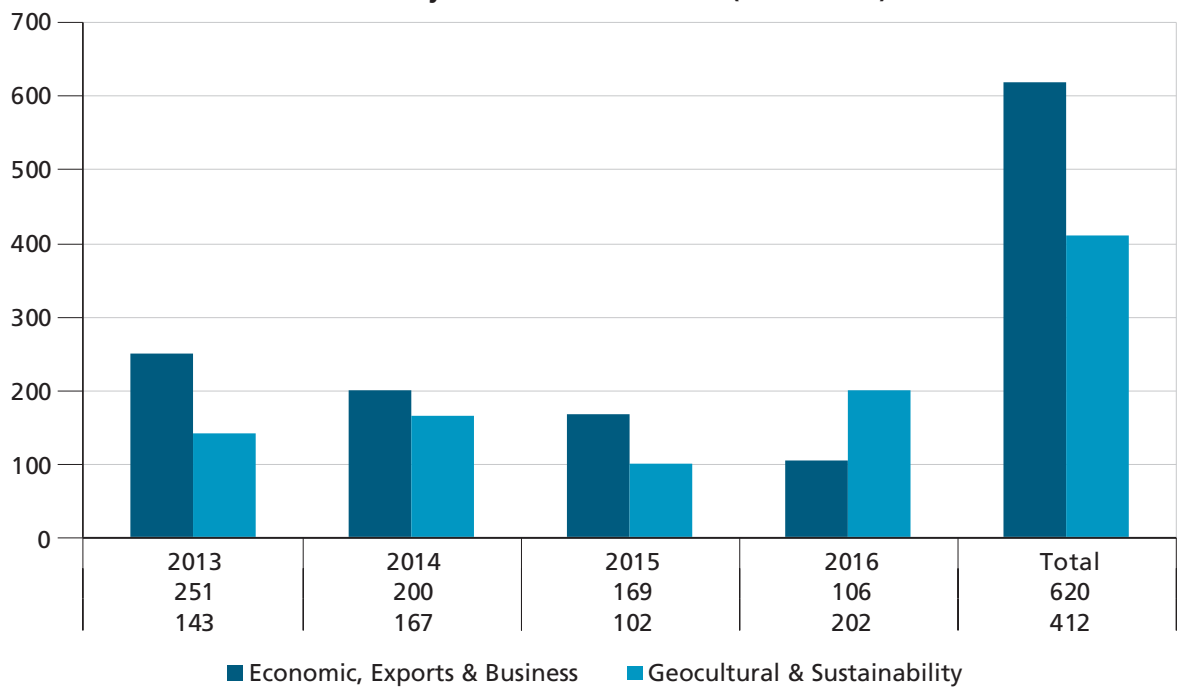

Authors' elaboration.

It is possible to notice that the amount of news in the thematic dimension of "Economic, Exports and Business" was higher than the ones on "Geocultural and Sustainability", although in 2016 the trend was reversed, probably because of the coverage of a natural disaster in Brazil. The total of data analysed and collected were 1,452 news articles; however, considering the thematic dimension classifications, the total of the data turns out to be 1,032 .

As a result, chart 5 signposts the "Economic, Exports and Business" dimension, which had the highest number of nodes, by presenting the following top five subdimensions: first, "government"; second, "finance"; third, "UK business \& global business"; and fourth, "politics"; and fifth, "agribusiness, oil \& ethanol". The remaining sub-themes not showed in chart 5 due to the scarce number of news were the following - "investment"; "tourism"; "corruption"; "diplomatic issues"; "internet, social media \& mobile"; interestingly, the last ones were "fashion" and "poverty". 


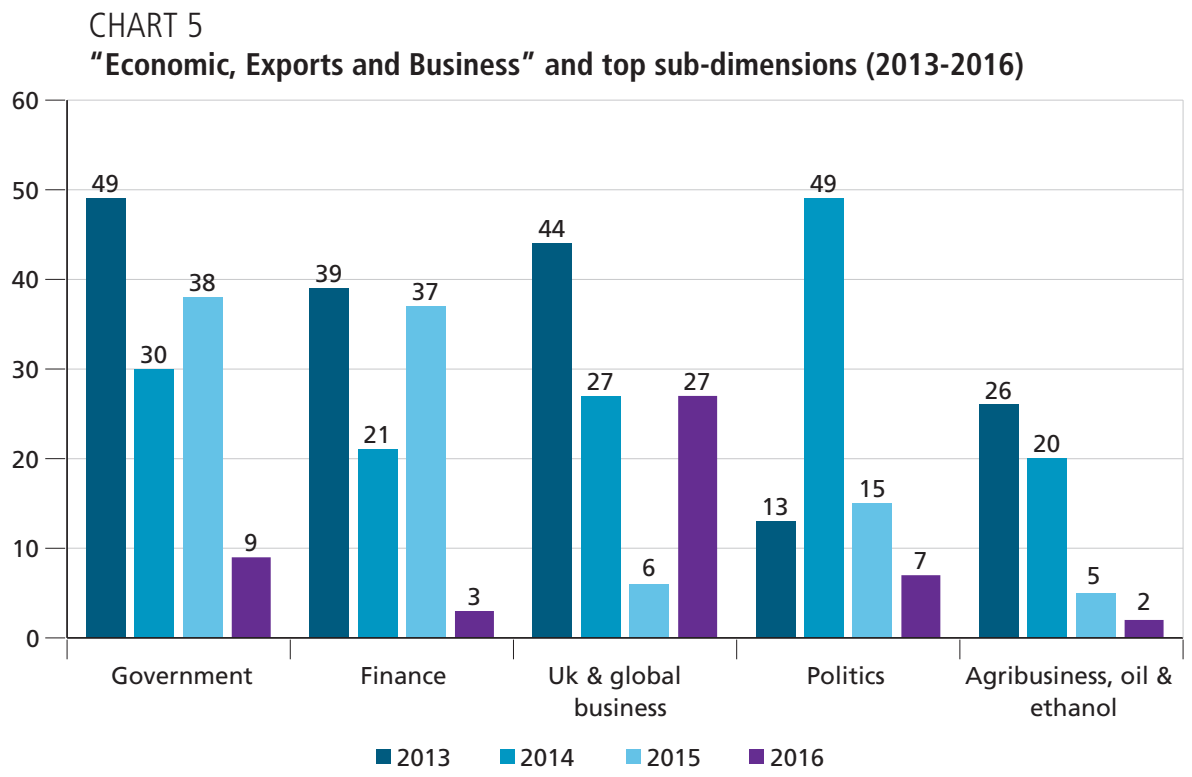

Authors' elaboration.

On the other hand, the "Geocultural and Sustainability" thematic dimension demonstrated the following sub-dimensions: first, "sports"; second, "environmental issues"; third, "crime"; then, forth, "religion"; and fifth, "television \& radio". Chart 6 presents a comparison among the top five sub-dimensions for each main dimension across the study period. Chart 6 does not show the next sub-themes due to the scarcity of the number of news, which were the following ones: "accidents", followed by an even distribution for "music", "food" and "dance".

CHART 6

"Geocultural and Sustainability" and top sub-dimensions (2013-2016)

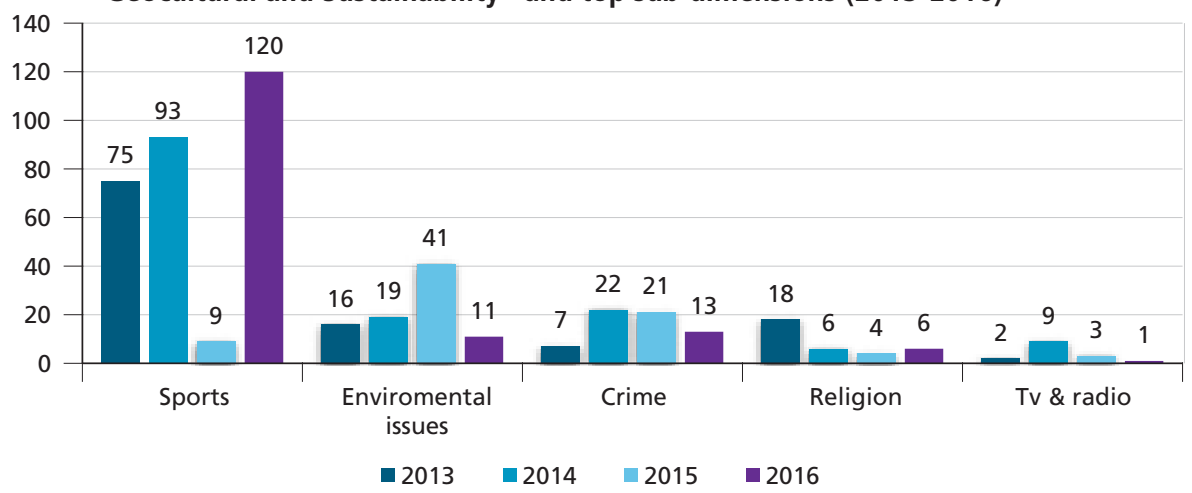

Authors' elaboration. 


\subsection{Quantitative analysis: word frequency}

In addition to news nodes established during the coding process in NVivo, there were particular words - associated to Brazil's image, which were repeatedly mentioned in the news coverage. Moreover, these words were, deductively, emerged from the data analysis; most of them are interestingly associated to the former thematic dimensions - inductively established a prior in the research for the start of NVivo coding.

Using NVivo tool for the selection of the 500 words most cited in the news coverage, the results were exported to an Excel file and investigated as well. For instance, out of 500, 150 words were considered after deleting frequent word which are from the news captions and the newspapers cataloguing, e.g. edition, comment, publication, section, length, copyright, documents, newspaper, among many others. Prepositions, connectors, verbs and adverbs were also removed.

"Brazil" was counted 4,128 times, which represents $1.52 \%$ weighted percentage (\%) of the total of 500 words mentioned in the news coverage. Next, the top 30 most frequent words related to the total of news are presented in chart 7.

\section{CHART 7}

Top 30 most frequent words related to Brazil in the analysed news

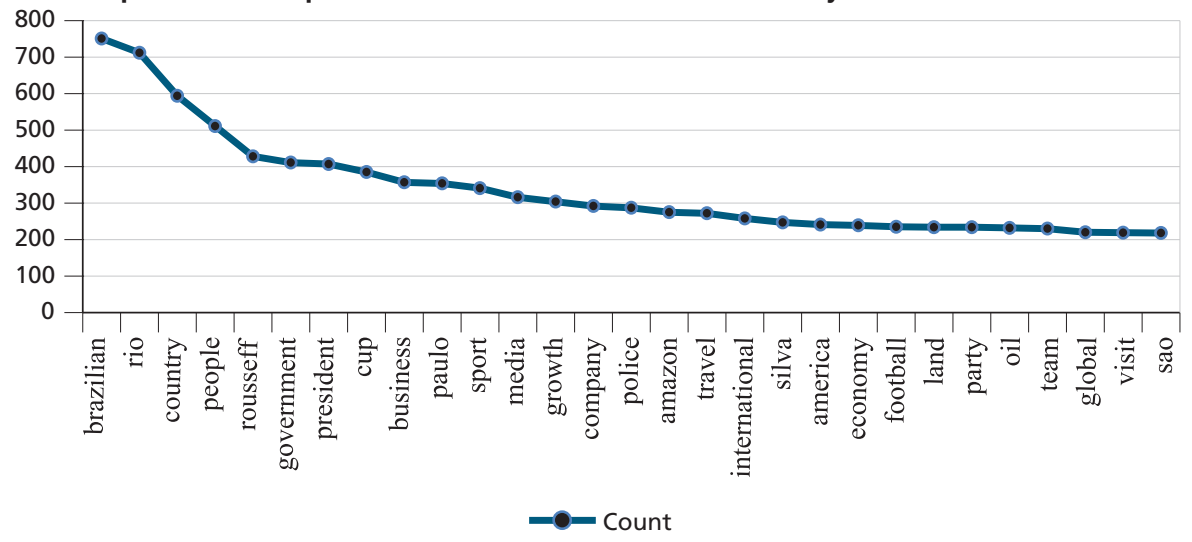

Authors' elaboration.

\subsection{Ambiguous interpretations}

Ambiguous interpretations of a few news articles were detected that justifies the total of analysed news discrepancy with the whole dataset collected $(1,452)$ regarding the thematic and the image classifications. For instance, The Independent on Sunday (Knight, 2012), on March 4, 2012 First Edition (88 of 109), publishes the headline "They've got an awful lot of potential in Brazil - and not just in coffee" with no section related. Moving forward to the whole news article page (106), it 
says "Think Brazil and what pops into your head? Carnival, football or the girl from Ipanema perhaps, but bumper investment returns? Unlikely". In this case, as in a few others, the journalist attracts the reader by using Brazilian stereotypes or image associations, however, the main theme is the economy, the BRICS, the investors, among others. Cases like this one, even though could imply more than one node (music $\&$ festivals; tourism $\&$ destinations; sports and economy), the researcher kept the main theme after reading carefully the whole news article. This way, there was not any second interpretation.

Another example of multiple interpretations because of the variety of topics within one news article also because of the lack of the suitable section, is one about Prince Harry's trip to Brazil in the News section. The news issued at The Sunday Telegraph (Nikkhah, 2012), on March 11, 2012 Edition 1, National Edition, has no straight focus, it mentions his role as an ambassador for British trade and the Olympics - on his first solo tour - playing rugby at Rio de Janeiro beach - which headline says: "Harry a sport in Brazil"; clearly, after reading the whole text (three lines only) at least two thematic dimensions could be seem in the news article: business with UK, sport, tourism destination. Another Royal family related-news is about the previous Harry's visit to the country, however, the headline at The Daily Telegraph, March 13, 2012 Tuesday Edition 1, National Edition, says: "Air traffic doubles as Harry visit boosts Brazil" (Gribben, 2012). In this case, the news section is Business, appropriately in a way; the text again emphasizes his role as a trade ambassador but finalizes highlighting that the percentage increase in flights between Heathrow and Brazil in the year to February. It could be classified either as UK business with Brazil or tourism.

However, there were a few news articles which had no relation to either the thematic dimensions or to the country image type, in this way, the classification as a "non topic" node was designated; for instance, The Times - both on March 10, 2012 National Edition and on March $8^{\text {th }} 2012$ in Ireland, reproduces the headline: "Inside today In Brazil now" (Inside..., 2012); when reading the short news article (only 48 words), the use of the slang "Phwoar" has no relation to a topic itself or a clear understanding of the news content. Furthermore, one news can be published in more than one edition of the same newspaper but in another country or city, for instance, The Times (London) publishes exactly the same news at the same day (or not) at the Ireland edition, at the Scotland edition and at the National edition as well. In this case, it was considered two news articles about Sport, in this case (September 20 ${ }^{\text {th }}, 2012$ ). 


\section{FINAL REMARKS}

The aim of this paper was to explore and analyse the projection of the image of Brazil in news articles from UK broadsheets in order to understand how media debates impact a country's image - in this case, the unit of analysis was Brazil. Our study joins others in country image research that have studied the news coverage within and about particular countries, including Chile (Jiménez-Martinez, 2013), the United States (Lee and Hong, 2012), Mexico (Rivas, 2011) and Portugal (Custódio and Gouveia, 2007). Our research builds on previous literature's suggestion that the analysis of media supports the overall understanding of the reputation of a country.

We categorized the 1,452 news articles into two thematic dimensions (1,032 news) and classified them as either positive, negative, or neutral (1,206 news). Moreover, each dimension produced several sub-dimensions, which underscores the multidimensional nature of country reputation. UK news coverage portrays "business" as the main theme. Further analysis showed that the "Economic, Exports and Business" thematic dimension reported significantly more news than the "Geocultural and Sustainability" thematic dimension in both years. Moreover, most of the news in the former dimension focused on government issues, politics, and Brazil's relationships with business entities inside and outside the UK. It is worth noting that both years featured important governmental and political issues - the reelection of the president and her frequent international appearances; the government's response to the economic situation; issues of corruption; street demonstrations, and an increase in business due to global trade. On the other hand, most of the news regarding the "Geocultural and Sustainability" dimension covered a range of themes, including sports, the environment and crime in both years as well - in terms of the volume of articles. Notably, 2014 saw twenty-four more articles regarding sports than 2013, likely prompted by preparations for the World Cup. During the same time span, there was a large increase in articles concerning crime.

Surprisingly, "neutral" news represented the highest number in both years (2013 and 2014), followed by "negative" and then "positive". Between 2013 and 2014, there was an increase in positive and neutral news, but a decrease in negative news. However, looking at the data at the semester level reveals further nuances: From January to June 2013, for instance, there was more negative coverage due to the economic downturn and street demonstrations. From July to December 2013, there was a slight decrease in the volume of news - even though Brazil was selected to host the Olympics 2016 in Rio de Janeiro. From January to June 2014, Brazil hosted the World Cup (July 2014), while street demonstrations during and after the mega-event were mostly contained to several host cities. Negative news remained about the same during this semester, while positive news rose slightly, and neutral news rose considerably. Lastly, the period covering July to December 2014 featured the presidential re-election and other street demonstrations through the country. 
In 2015 there was an increase in the proportion of news with a negative tone, which is aligned with the fact that it was a period in the middle of the two global events hosted by Brazil. In that year, the world was still paying a lot of attention to the country, but there was no escape from the factual news about the problems of the country, and there was not a lot of need for coverage of sports and cultural events. According to the Reputation Magazine (Transparency..., 2016, p. 2) by the Oxford University Centre for Corporate Reputation, "Brazil is in meltdown, after nearly two years of what has been called the biggest global corruption scandal ever, with graft and conspiracy identified in epidemic proportions between stateowned oil company Petrobras, construction companies and political leaders". These serious complications - between having rich natural resources, on one hand, and a tendency toward corruption on the other - are damaging Brazil's country reputation. However, the political or social dimensions of Brazil are beyond the scope of this research, even though it is relevant to hold onto these existing evidences of transitional issues (Szondi, 2007).

It is worth cautioning that there was an abundance of negative news coverage across all four years. Nonetheless, the findings offer qualitative support to earlier authors' suggestions - for instance, that socio-economic changes may repair or modify a country image. Furthermore, it seems that strategies of country reputation management, in collaboration with media entities, can change negative or false stereotypes. Our results suggest that government officials can leverage books, films, and other media in order to enhance tourism and conduct PR campaigns, which may ultimately improve the country's branding.

Several authors have noted that country image is a key construct in international public relations and diplomacy. In this regard, our results emphasize that a country's image (and by extension, its reputation) can be deduced from positive and negative news coverage in the international press. To achieve this clarity, place marketers and officials need to consider the thematic dimensions and sub-dimensions in order to grasp the indirect way in which media relations shape a country image (Walker, 1997).

Taken together, these results suggest that there is a link between the country status quo and its projected image in the news media that stems from the country's socio-economic, political, geocultural, and sustainability aspects and changes. Consequently, governments may be able to better plan their media relations by monitoring the country image: for instance, our sample was devoid of news regarding "education" and "technology"; such positive topics could have been internationally disseminated. For instance, none of the UK papers in our sample covered news regarding education and technology. However, Brazil undertook actions in both domains during 2013 and 2014 - respectively funding higher education, both internally and externally, and supporting Embraer aircrafts and 
software exports. At the same time, external news may indicate a need for internal solutions: For instance, the high emphasis on "crime" in the UK news suggests that the government needs to coordinate with public and private institutions to improve the issue internally.

Although this paper supports the idea that media analysis can improve our general understanding of a place brand, it features several limitations that may prompt further research. Due to timing and resources, we were unable to gather data from a wider number of online media sources, such as blogs, magazines and forums. Additionally, our study did not factor in the bias or orientation of any given newspaper. That said, this was not a study of the media itself or people's perceptions towards news content. Another constraint lies in the fact that this study had no intention to analyse Brazil's image under an entire political or social angle as, during the data collection, problems concerning the political dimension could have been explored due to the on-going in-country social and political. However, the reality of the country was addressed by citing the main events during these years (2013, 2014, 2015 and 2016). Moreover, in all situations, attention is needed between the promise of country branding and the reality of the country; thus, government and public and private partnership are required in order to prioritise public policies planning focusing on the reputation of the country. As a recommendation for future research, the proposed framework — thematic dimensions and image types — of this research may be potentially applied to other time (e.g. years, decades or months) or space (e.g. cities, regions or countries).

On a practical level, our study implies that governments should commit the appropriate investment and planning to strategies and activities that mitigate a country's negative image. This paper also endorses that governments could validate their function by highlighting (positive) changes and (virtuous) improvements as part of their country's brand communication, international public relations and public diplomacy initiatives.

\section{REFERENCES}

ADEGOJU, A. We need more than jingles: discursive practices of resistance in the Nigerian public's responses to the rebranding Nigeria campaign. Discourse, Context \& Media, p. 106-13, 2016.

ANHOLT, S. Places: identity, image and reputation. London: Palgrave Macmillan, 2010.

APEX-BRASIL - AGÊNCIA BRASILEIRA DE PROMOÇÃO DE EXPORTAÇÓES E INVESTIMENTOS. Discover Brazil. Apex-Brasil, 2016. Retrieved Jan. 27, 2016, from: <https://bit.ly/3eF0VQK>. 
BANDEIRA, L. 'Imagem internacional do Brasil não poderia estar pior', diz brasilianista. BBC Brasil in London, Mar. 5, 2016. Retrieved May 10, 2016, from: <https://bbc.in/30q6NrU>.

BAZELEY, P.; JACKSON, K. Qualitative data analysis with NVivo. 2. ed. London: Sage, 2013.

BNA - BRITISH NEWSPAPER ARCHIVE. Brazil News. The BNA, 2015. Retrieved Mar. 2015, from: <https://bit.ly/3hRoLve>.

BRAZIL's last emperor deposed. History, [s.d.]. Retrieved Nov. 17, 2015, from: $<$ https://bit.ly/3gMoRCP>.

BRAZIL's political turmoil hangs over agricultural markets. The Financial Times, 2016. Retrieved Apr. 28, 2016, from: <https://on.ft.com/32JTbZY>.

BUARQUE, D. One country, two cups - the international image of Brazil in 1950 and in 2014: a study of the reputation and the identity of Brazil as projected by the international media during the Two FIFA World Cups in the country. International Journal of Communication, v. 9, p. 1300-1318, 2015.

. Crises, corrupção e zika criam tormenta, mas não destroem imagem do Brasil. Blog do Brasilianismo/Uol, 2016. Retrieved July 2018, from: <https:// bit.ly/2DQSrJJ>.

BUHMANN, A.; INGENHOFF, D. Advancing the country image construct from a public relations perspective. Journal of Communication Management, v. 19, n. 1, p. 62-80, 2015.

CUSTÓDIO, M.; GOUVEIA, P. Evaluation of the cognitive image of a country/ destination by the media during the coverage of mega-events: the case of UEFA EURO 2004 in Portugal. International Journal of Tourism Research, v. 9, n. 4, p. 285-296, 2007.

DINNIE, K. Nation branding: concepts, issues, practice. 2. ed. Oxon: Routledge, 2015.

FETSCHERIN, M. How to brand nations, cities and destinations: a planning book for place branding. International Marketing Review, v. 27, n. 4, p. 480483, 2010.

FILL, C. Essentials of marketing communications. Upper Saddle River: Prentice Hall, 2011.

FORTUNATI, L.; TAIPALE, S.; FARINOSI, M. Print and online newspapers as material artefacts. Journalism, p. 1-18, 2014.

GHERSETTI, M. Still the Same? Journalism Practice, v. 8, n. 4, p. 373-389, 2014. 
GIRALDI, J. M. E. Evaluation of the impact of Brazil's sustainability on the behavioural intentions of stakeholders toward the country. Evaluation and Program Planning, v. 54, p. 135-143, 2016.

GRIBBEN, R. Air traffic doubles as Harry visit boosts Brazil. The Daily Telegraph, Mar. 13, 2012.

GUINA, F. C.; GIRALDI, J. M. E. The evaluation of Brazilian beef in Europe: consumers, importers and exporters' perspectives. International Food and Agribusiness Management Review, v. 16, n. 4, p. 101-122, 2013.

GUNTER, B. News sources and news awareness: a British survey. Journal of Broadcasting \& Electronic Media, v. 29, n. 4, p. 397-406, 1985.

Media research methods. London: Sage, 2000.

HANSEN, A.; MACHIN, D. Media and communication research methods. London: Palgrave MacMillan, 2013.

INGENHOFF, D. Migration and Swiss identity: how much space for the foreign in the familiar? Studies in Communication Sciences, v. 17, n. 1, p. 137-140, 2017. INSIDE today in Brazil now. The Times, Mar. 8, 2012.

JAIN, R.; WINNER, L. Country reputation and performance: the role of public relations and news media. Place Branding and Public Diplomacy, v. 9, n. 2, p. 109-123, 2013.

JIMÉNEZ-MARTINEZ, C. Chile's quest to improve its image abroad. Place Branding and Public Diplomacy, v. 9, n. 4, p. 279-290, 2013.

Which Image? Of Which Country? Under Which Spotlight? Power, Visibility, and the Image of Brazil. Revista Trama Interdisciplinar, v. 8, n. 3, p. 52-70, 2017.

KIM, J. Y.; YANG, S. Effects of government public relations on international news coverage. Public Relations Review, v. 34, n. 1, p. 52-53, 2008.

KNIGHT, J. They've got an awful lot of potential in Brazil - and not just in coffee. The Independent on Sunday, Mar. 4, 2012. Available at: <https://bit. ly/2YVb3Qn>.

LE, E. Gateways to the news: headlines on Le Monde's home page and front page. Discourse, Context and Media, v. 1, n. 1, p. 32-44, 2012.

LEE S.; HONG, H. International public relations' influence on media coverage and public perceptions of foreign countries. Public Relations Review, v. 38, n. 3, p. 491-493, 2012. 
LEXISNEXIS. Search. LexisNexis, 2014. Retrieved Jan. 2015, from: <www. lexisnexis-es.co.uk/>.

LOO, T.; DAVIES, G. Branding China: the ultimate challenge in reputation management? Corporate Reputation Review, v. 9, n. 3, p. 198-210, 2006.

LOPES, I. B.; GIRALDI, J. M. E.; AGUIAR, L. An Analysis of country image of Brazil and its fresh fruits: a two scales comparison. Journal of Food Products Marketing, v. 20, p. 262-282, 2014.

LOURENÇÃO, M.; GIRALDI, J. M. E. Development of an identity model for sector brands. Journal of Fashion Marketing and Management, v. 21, n. 3, p. 317-340, 2017.

MARIUTTI, F. The Placement of country reputation towards place management. Journal of Place Management and Development, v. 10, n. 3, p. 240-253, 2017.

MARIUTTI, F. et al. 'If I huff and puff - Foundations for building Brazil's image: evidence from an international systematic review. Revista Eletrônica de Negócios Internacionais ESPM, v. 12, n. 2, p. 58-73, 2017.

MARIUTTI, F.; GIRALDI, J. D.; CRESCITELLI, E. The image of Brazil as a tourism destination: an exploratory study of the American market. International Journal of Business Administration, v. 4, n. 1, p. 13-22, 2013.

MARIUTTI, F.; TENCH, R. How does Brazil measure up? Comparing rankings through the lenses of nation brand indexes. Place Branding and Public Diplomacy, v. 12, n. 1, p. 17-31, 2016.

MOILANEN, T.; RAINISTO, S. How to brand nations, cities, and destinations: a planning book for place branding. London: Palgrave Macmillan, 2009.

MORLEY, M. How to manage your global reputation: a guide to the dynamics of international public relations. New York: Palgrave, 2002.

NEWBURRY, W. Waving the flag: the influence of country-of-origin on corporate reputation. In: BARNETT, M. L.; POLLOK, T. G. (Eds.). The oxford handbook of corporate reputation. Oxford: Oxford University Press, 2012. p. 240-257.

NGHIÊM-PHÚ, B. Projected Country Image: an investigation of provinces/cities' logos. Asia Pacific Journal of Tourism Research, v. 20, p. 1466-1485, 2015.

NIKKHAH, R. Harry a sport in Brazil. The Sunday Telegraph, Mar. 11, 2012.

RICHARDSON, J. E. Analysing newspapers: an approach from critical discourse analysis. London: Palgrave Macmillan, 2007. 
RIVAS, C. V. The rise and fall of Mexico's international image: stereotypical identities, media strategies and diplomacy dilemmas. Place Branding and Public Diplomacy, v. 7, n. 1, p. 23-31, 2011.

ROCHA, A. A. Brasil: a paradise of paradoxes. Americas, v. 52, n. 2, p. 28-37, 2000. Retrieved Mar. 23, 2015, from: <https://bit.ly/2Ckkkt2>.

SANTOS, G. E. O.; GIRALDI, J. M. E. Reciprocal effect of tourist destinations on the strength of national tourism brands. Tourism Management, v. 61, p. 443-450, 2017.

SAUNDERS, M.; LEWIS, P.; THORNHILL, A. Research methods for business students. 5. ed. London: Pearson, 2009.

SCHREIER, M. Qualitative content analysis in practice. In: FLICK, U. The SAGE handbook of qualitative data analysis. London: Sage, 2013. p. 170-183.

SUTTER, M. B. et al. In search of tools for the use of country image (CI) in the brand. Journal of Brand Management, v. 25, p. 1-14, 2018.

SZONDI, G. The role and challenges of nation branding in transition countries: the Central and Eastern European experience. Place Branding and Public Diplomacy, v. 3, n. 1, p. 8-20, 2007.

From image management to relationship building: a public relations approach to nation branding. Place Branding and Public Diplomacy, v. 6, n. 4, p. 333-43, 2010.

. Public diplomacy. In: HEATH, R. L. (Ed.). Encyclopedia of public relations. 2. ed. Thousand Oaks: Sage, 2013. p. 711-712.

TENCH, R.; BOWD, R.; JONES, B. FewerPerceptions and perspectives: corporate social responsibility and the media. Journal of Communication Management, v. 11, n. 4, p. 348-370, 2007.

THE GUARDIAN view on Dilma Rousseff's impeachment: a tragedy and a scandal. The Guardian, Apr. 18, 2016. Retrieved Apr. 28, 2016, from: <https:// bit.ly/2OATnnK>.

TOLEDANO, M.; MCKIE, D. Public relations and nation branding: influencing Israel. New York: Routledge, 2013.

TRANSPARENCY versus Bribery. Reputation Magazine, n. 15, p. 1-12, 2016.

WALKER, D. Public relations in local government: strategic approaches to better communication. London: Pitman, 1997. 
WATTS, P. Brazil: war photographer André Liohn documents a country in chronic disorder. The Independent, Mar. 12, 2016. Retrieved Apr. 28, 2016, from: <https:// bit.ly/2OMVxAN>.

WORLD BANK. Overview. The World Bank, 2017. Retrieved Mar. 2017, from: <https://bit.ly/30rW0Oe>.

\section{COMPLEMENTARY BIBLIOGRAPHY}

APEX-BRASIL - AGÊNCIA BRASILEIRA DE PROMOÇÃO DE EXPORTAÇÓES E INVESTIMENTOS. Apex-Brasil trade sectors projects. Apex-Brasil, 2010. Retrieved May 14, 2014, from: <https://bit.ly/2WocZPV>.

DAYMON, C.; HOLLOWAY I. Qualitative research methods in public relations and marketing communications. 2. ed. London: Routledge, 2011.

Data de submissão: 16/11/2017

Primeira decisão editorial em: 18/7/2018

Última versão recebida em: 17/8/2018

Aprovação final em: 18/9/2018 



\section{Ipea - Instituto de Pesquisa Econômica Aplicada}

\section{EDITORIAL}

\section{Coordenação}

Reginaldo da Silva Domingos

\section{Assistente de Coordenação}

Rafael Augusto Ferreira Cardoso

\section{Supervisão}

Camilla de Miranda Mariath Gomes

Everson da Silva Moura

\section{Revisão}

Amanda Ramos Marques

Ana Clara Escórcio Xavier

Clícia Silveira Rodrigues

Idalina Barbara de Castro

Luiz Gustavo Campos de Araújo Souza

Olavo Mesquita de Carvalho

Regina Marta de Aguiar

Hellen Pereira de Oliveira Fonseca (estagiária)

Ingrid Verena Sampaio Cerqueira Sodré (estagiária)

\section{Editoração}

Aeromilson Trajano de Mesquita

Cristiano Ferreira de Araújo

Danilo Leite de Macedo Tavares

Herllyson da Silva Souza

Jeovah Herculano Szervinsk Junior

Leonardo Hideki Higa

\section{Capa}

Herllyson da Silva Souza

The manuscripts in languages other than Portuguese

published herein have not been proofread.

\section{Livraria Ipea}

SBS - Quadra 1 - Bloco J - Ed. BNDES, Térreo

70076-900 - Brasília - DF

Tel.: (61) 2026-5336

Correio eletrônico: livraria@ipea.gov.br 

Composto em adobe garamond pro 11/13,2 (texto)

Frutiger 67 bold condensed (titulos, gráficos e tabelas) Brasília-DF 